\title{
ANALISIS PERBEDAAN KINERJA KEUANGAN BANK UMUM PEMERINTAH DAN BANK SWASTA NASIONAL YANG TERDAFTAR DI BURSA EFEK INDONESIA PERIODE 2013-2017
}

\author{
Endang Purwanti \\ STIE AMA Salatiga \\ endangpurwanti@stieama.ac.id
}

\begin{abstract}
ABSTRAK
Kinerja Bank merupakan pertimbangan yang cukup penting dan signifikan bagi pihak yang berkepentingan pada Bank halini dikarenakan berfungsi sebagai perantara keuangan. Tujuan penelitian membandingkan kinerja keuangan Bank Umum Pemerintah (BUMN) dan Bank Umum Swasta Nasional yang diukur dengan Return On Asset (ROA) dan Return On Equity (ROE) periode 2013 -2017 Metode penelitian yang digunakan analisis uji beda rata-rata atau paired $T$ tes dengan hasil analisis diperoleh bahwa rata-rata ROA Bank Umum Pemerintah lebih tinggi dari pada Bank Umum Swasta Nasional. Rata-rata ROE Bank Umum Pemerintah lebih tinggi dari pada Bank Umum Swasta Nasional. Sedangkan dari hasil uji Paired T tes diperoleh hasil tidak ada perbedaan yang signifikan rata-rata ROA Bank Umum Pemerintah dengan rata-rata ROA Bank Umum Swasta Nasional selama periode 2013 -2017. Sedangkan ROE diperoleh hasil ada perbedaan yang signifikan rata-rata ROE Bank Umum Nasional dengan rata-rata ROE Bank Umum Swasta Nasional selama periode 2013 -2017. ROE merupakan faktor yang penting bagi investor atau calon investor, karena apabila ROE tinggi kesejahteraan para pemegang saham juga tinggi, perbedaan yang dikarenakan Bank Umum Pemerintah sudah mempunyai kepercayaan bagi masyarakat sehingga banyak investor dan calon investor membeli saham Bank tersebut. Apabila dilihat dari ROA kedua Bank tersebut dalam pengelolaan asset sudah menjalankan prinsip pruden atau kehati hatian dan azas taat patuh pada aturan. Dari hasil penelitian dapat disarankan Bank Umum Pemerintah dapat mempertahankan atau meningkatkan kinerja keuangannya dengan cara selalu menekankan pengawasan yang ketat, sedangkan Bank Swasta Umum Nasional dapat meningkatkan kepercayaan kepada nasabah dengan pengelolaan manajemen yang baik dan tetap menjaga prinsip kehati-hatian dalam menjalankan kegiatannya.
\end{abstract}

Kata Kunci : Kinerja Keuangan, Bank

\section{PENDAHULUAN}

Perbankan di Indonesia telah mengalami pasang surut berbagai peristiwa penting telah mewarnai dan membentuk arah ekonomi global, peristiwa - peristiwa itu diantaranya adalah krisis sistem moneter internasional (bretton woods), krisis utang luar negeri, krisis minyak dan komoditas primer lainnya hingga pada akhirnya industri perbankan terpuruk sebagai imbas dari terjadinya krisis moneter dan krisis ekonomi yang melanda perekonomian Indonesia pada tahun 1997. Masalah lain yang muncul adalah terpuruknya citra sektor perbankan, terutama karena kredit macet perusahaan - perusahaan besar yang sangat berpengaruh pada likuiditas di hampir semua bank yang ada di Indonesia. (Dendawijaya, 2005) Hal tersebut sangat 
berdampak negatif terhadap kinerja perbankan nasional yang semakin sulit mendapat kepercayaan penuh dari masyarakat, untuk mengatasi hal tersebut perbankan melakukan terobosan - terobosan baru untuk menggerakkan kembali roda perekonomian di Indonesia antara lain dengan melakukan restrukturisasi perbankan yang artinya adalah upaya perbaikan yang dilakukan dalam kegiatan perkreditan terhadap debitur yang mengalami kesulitan untuk memenuhi kewajibannya.

Performance (kinerja) bank menjadi pertimbangan yang signifikan bagi pihak-pihak yang berkepentingan pada bank. Pihak-pihak yang berkepentingan pada bank antara lain investor, kreditur, pelanggan, karyawan, pemerintah, dan masyarakat sekitar. Mengingat banyaknya pihak-pihak yang berkepentingan sehingga penilaian terhadap performance bank menjadi sangat penting. Performance bank tersebut dapat dilihat melalui laporan keuangan yang secara teratur diterbitkan oleh bank go public. Alat analisis yang digunakan untuk mengukur perormance salah satunya analisis laporan keuangan yang berupa rasiorasio laporan keuangan yaitu rasio rasio likuiditas, leverage atau solvabilitas, profitabilitas (Darsono dan Ashari, 2004). Rasio profitabilitas atau kemampu labaab dapat diukur dengan rasio return on asset (ROA) dimana rasio ini mengukur kemampuan perusahaan menghasilkan laba dengan mengggunakan total aset (kekayaan) yang dipunyai perusahaan setelah disesuaikan dengan biaya biaya untuk mendanai aset tersebut. Selain ROA rasio lain yang digunakan untuk mengukur laba yaitu return on equity (ROE) rasio ini secara eksplisit memperhitungkan kemampuan perusahaan menghasilkan laba bagi pemegang saham biasa setelah memperhitungkan bunga (biaya hutang) dan deviden saham preferen (biaya saham preferen). Yuli Christian (2009) melakukan penelitian analsisis perbedaan kinerja keuangan Bank Umum Pemerintah dan Bank Umum Swasta Nasional yang terdaftar di Bursa Efek Indonesia periode 2003-2007 yang diwakili oleh rasio keuangan yang terdiri dari CAR, ROA, NPM, ROA, BOPO, LDR, CAMEL deperoleh hasil terdapat perbedaan yang signifikan kinerja keuangan Bank Umum Pemerintah dan Bank Umum Swasta. Sedangkan peneltian Abraham dkk (2016) terdapat perbedaan signifikan CAR, ROA,ROE, LDR,BOPO Bank Konvensional dan Bank Syariah, namun NPL dan NPF tidak ada perbedaan yang signifikan. Berdasarkan latar belakang masalah yang telah diuraikan yang menjadi masalah penelitian adalah Apakah terdapat perbedaan yang signifikan antara kinerja Keuangan ( ROA dan ROE ) Bank Umum Pemerintah dan Bank Umum Swasta Nasional Yang Terdaftar di Bursa Efek Indonesia Periode 2013 $-2017$

Tujuan penelitian ini untuk menganalisis perbandingan dan melihat manakah kinerja keuangan yang lebih baik antatra Bank Umum Pemerintah dan Bank Umum Swasata Nasional yang terdaftar di BEI dengan menggunakan metode rasio keuangan ROA dan ROE selama periode 20013 - 2017. Penelitian ini diharapkan dapat memberikan manfaat Bagi Bank Umum Pemerintah dan Bank Umum Swasta Nasional yang dapat dijadikan sebagai catatan untuk mempertahankan dan meningkatkan kinerjanya serta sebagai bahan koreksi untuk memperbaiki apabila terdapat kelemahan. Membantu pemodal dalam mengambil keputusan dalam berinvestasi pada kedua bank tersebut. Bagi dunia pendidikan sebagai bahan diskusi mengenai karakteristik instrument Bank Umum Pemerintah dan Bank Umum Swasta Nasional. 


\section{LANDASAN TEORI DAN PENGEMBANGAN HIPOTESIS}

Menurut UU RI Nomor 10 Tahun 1998 Pasal I ayat 2: Bank adalah badan usaha yang menghimpun dana dari masyarakat dalam bentuk simpanan dan menyalurkannya kepada masyarakat dalam bentuk kredit dan atau bentuk-bentuk lainnya dalam rangka meningkatkan taraf hidup rakyat banyak. Dari segi kepemilikanya dapat dilihat dari akte pendirian dan penguasaan saham yang dimiliki Bank yang bersangkutan . Bank milik pemerintah akte pendirian dan modalnya dimiliki pemerintah, sehingga seluruh keuantungan Bank ini dimiliki oleh pemerintah. Sedangkan Bank Swasta seluruh atau sebagian modalnya dimiliki oleh swasta serta akte pendiriannya didirikan oleh swasta, begitu pula pembagian keuntungannya diambil oleh swasta. Keuntungan utama dari bisnis perbankan yang berdasarkan prinsip konvensional diperoleh dari selisih bunga simpanan yang diberikan kepada penyimpan dengan bunga pinjaman atau kredit yang disalurkan. Keuntungan dari selisih bunga ini di bank dikenal dengan istilah spread based. Apabila suatu bank mengalami kerugian dari selisih bunga, dimana suku bunga simpanan lebih besar dari suku bunga kredit, maka istilah ini dikenal dengan nama negatif spread.Disamping itu perbankan juga melakukan kegiatan jasa-jasa pendukung lainnya.Jasa-jasa ini diberikan untuk mendukung kelancaran kegiatan menghimpun dana dan menyalurkan dana, baik yang berhubungan langsung dengan kegiatan simpanan dan kredit maupun tidak langsung.

\section{Laporan Keuangan}

Munawir (2014) menjelaskan laporan keuangan merupakan hasil dari proses akuntansi yang dapat digunakan sebagai alat untuk berkomunikasi antara data keuangan atau aktivitas suatu perusahaan dengan pihak - pihak yang berkepentingan dengan data atau aktivitas perusahaan tersebut.Menurut PSAK No. 1 Tahun 2015, Laporan Keuangan adalah penyajian terstruktur dari posisi keuangan dan kinerja keuangan suatu entitas. Laporan ini menampilkan sejarah entitas yang dikuantifikasi dalam nilai moneter. Laporan keuangan merupakan bagian dari proses pelaporan keuangan. Laporan keuangan yang lengkap biasanya meliputi neraca, laporan laba rugi, laporan perubahan posisi keuangan (yang dapat disajikan dalam berbagai cara misalnya, sebagai laporan arus kas, atau laporan arus dana), catatan dan laporan lain serta materi penjelasan yang merupakan bagian integral dari laporan keuangan. Disamping itu juga termasuk skedul dan informasi tambahan yang berkaitan dengan laporan tersebut, misalnya, informasi keuangan segmen industri dan geografis serta peningkatan pengaruh perubahan harga.Harahap (2015) laporan keuangan adalah media informasi atau komunikasi yang merangkum semua aktivitas perusahaan. Sedangkan, menurut Kasmir (2014) laporan keuangan adalah laporan yang menunjukan kondisi keuangan perusahaan saat ini atau dalam suatu periode tertentu.

\section{Analisis Laporan Keuangan}

Harahap (2015) analisis laporan keuangan upaya mencari hubungan antara berbagai pos atau komponen yang ada dalam laporan keuangan perusahaan.Sedangkan rasio keuangan adalah angka yang diperoleh dari hasil perbandingan dari satu pos laporan keuangan dengan pos lainnya yang mempunyai hubungan yang relevan dan signifikan. Rasio keuangan hanya menyederhanakan informasi yang menggambarkan hubungan pos tertentu dengan pos lainnya, sehingga dapat dengan cepat menilai hubungan antar pos dan membandingkannya dan pada akhirnya didapatkan sebuah informasi..Rasio yang biasa digunakan untuk mengukur 
dan membandingkan kinerja profitabilitas bank adalah ROE (Return on Equity) dan ROA (Return on Assets). ROE menunjukan kemampuan manajemen bank dalam mengelola modal yang tersedia untuk mendapatkan net income. Semakin tinggi return semakin baik karena berarti dividen yang dibagikan atau ditanamkan kembali sebagai retained earning juga akan semakin besar. Menurut Damayanti dalam Purwanto (2003), pengukuran kinerja perusahaan dapat dinilai dari dua sudut pandang, sudut pandang finansial, berupa pengukuran kinerja perusahaan dari aspekaspek financial perusahaan seperti likuiditas, solvabilitas, rentabilitas dan lainlain.Sudut pandang nonfinansial, berupa pengukuran dari aspek-aspek nonfinansial seperti kepuasan pelanggan dan pengembangan perusahaan.Dari aspek-aspek di atas yang terpenting adalah pengukuran dilihat dari laporan keuangan dan diukur melalui rasio keuangan. Secara empiris, rasio keuangan terbukti memiliki kemampuan menjelaskan maupun memprediksi kinerja keuangan cukup akurat.

\section{ROA (Return on Asset)}

Analisis Return on Asset atau sering disebut rentabilitas ekonomi merupakan kemampuan atau potensi perusahaan dalam menghasilkan laba dimasa lalu. Analisis return on asset mengukur kemampuan atau potensi perusahaan menghasilkan laba dengan menggunakan total aset (kekayaan) yang dipunyai perusahaan setelah disesuaikan dengan biaya - biaya untuk mendanai aset tersebut. biaya - biaya pendanaan yang dimaksud adalah bunga yang merupakan biaya pendanaan dengan hutang. Biaya bunga ditambahkan ke laba yang diperoleh perusahaan, maka dari itu return on asset bisa di interpretasikan sebagai hasil dari serangkaian kebijakan perusahaan (strategi) dan merupakan pengaruh dari faktor - faktor lingkungan (environmental factors). (Mamduh, 2005)Menurut Dendawijaya (2005) rasio Return on Asset merupakan rasio untuk mengukur atau sebagai indikasi kemampuan manajemen bank dalam memperoleh keuntungan (laba) secara keseluruhan. Semakin besar return on asset suatu bank, semakin besar pula tingkat keuntungan yang dicapai bank tersebut dan semakin baik pula posisi bank tersebut dari segi penggunaan aset. ROA juga merupakan salah satu bentuk rasio profitabilitas yang di tujukan untuk mengukur kemampuan perusahaan dengan seluruh dana yang digunakan untuk operasional perusahaan untuk menghasilkan laba.Return on asset (ROA) menunjukan kemampuan manajemen bank dalam menghasilkan income dari pengelolaan aset yang dimiliki. (Kuncoro:2007).Sedangkan Dendawijaya (2005) rasio Return on Asset merupakan rasio untuk mengukur kemampuan manajemen bank dalam memperoleh keuntungan (laba) secara keseluruhan. Semakin besar return on asset suatu bank, semakin besar pula tingkat keuntungan yang dicapai bank tersebut dan semakin baik pula posisi bank tersebut dari segi penggunaan aset. ROA merupakan salah satu bentuk rasio profitabilitas yang di tujukan untuk

\section{Return On Equity (ROE)}

Return on Equity (ROE) merupakan rasio yang secara eksplisit memperhitungkan kemampuan perusahaan menghasilkan laba bagi pemegang saham biasa setelah memperhitungkan bunga (biaya hutang) dan deviden saham preferen (biaya saham preferen).(Mamduh, 2005).Menurut Dendawijaya (2005) Return on Equity (ROE) adalah perbandingan antara laba bersih bank dengan return on equity modal sendiri, rasio ini banyak diamati oleh para pemegang saham bank baik pemegang saham pendiri maupun pemegang saham baru serta para investor di pasar modal yang ingin membeli saham bank yang bersangkutan (jika bank tersebut telah go public). Rasio ini merupakan indikator yang amat 
penting bagi para pemegang saham dan calon investor untuk mengukur kemampuan bank dalam memperoleh laba bersih yang dikaitkan dengan pembayaran deviden. Kenaikan dalam rasio ini berarti terjadi kenaikan laba bersih dari bank yang bersangkutan yang menyebabkan kenaikan pada harga saham bank. Menurut Tandelilin (2010) Return on Equity (ROE) umumnya dihitung menggunakan ukuran kinerja berdasarkan akuntansi dan dihitung sebagai laba bersih perusahaan dibagi dengan ekuitas pemegang saham biasa. Kasmir (2014) menjelaskan Return on Equity merupakan rasio untuk mengukur laba bersih sesudah pajak dengan modal sendiri.Kerangka Pemikiran

\section{MODEL PENELITIAN}

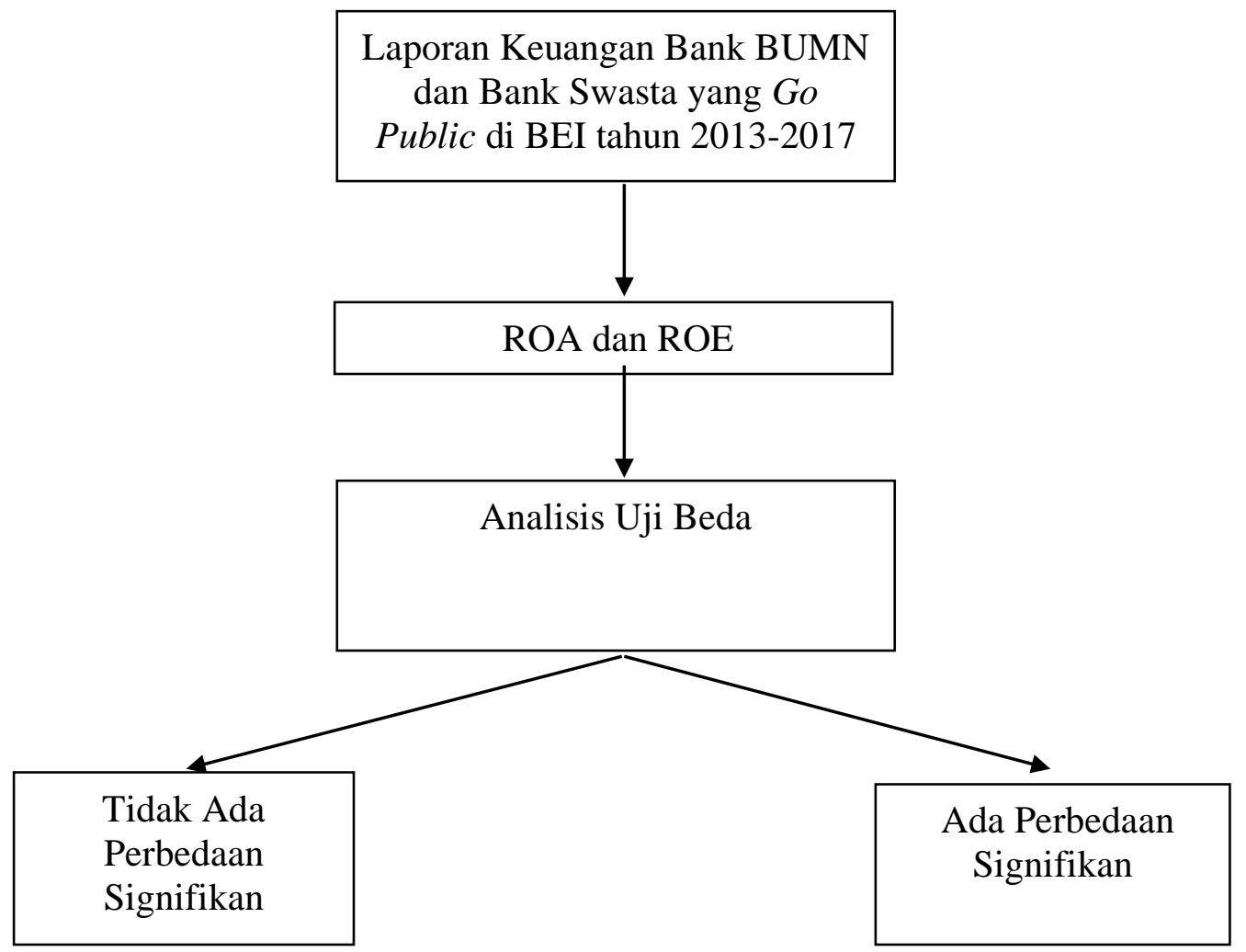

Gambar 1. Kerangka Pikir Penelitian

\section{Hipotesis}

Hipotesis Penelitian adalah jawaban sementara terhadap masalah penelitian, yang kebenarannya masih harus di uji secara emperis. Hipotesis pada penelitian ini adalah sebagai berikut :

$\mathrm{H}_{1}$ : Terdapat perbedaan yang signifikan ROA Bank Umum Pemerintah dengan Bank Umum Swasta Nasional yang terdaftar di BEI periode 2013-2017.

$\mathrm{H}_{2}$ : Tedapat perbedaan yang signifikan ROE Bank Umum Pemerintah dengan

Bank Umum Swasta Nasional yang terdaftar di BEI periode 2013-2017

\section{METODE PENELITIAN}


Tipe penelitian yang digunkan dalam penelitian ini adalah penelitian diskriptif, dimana merupakan penelitian dilakukan untuk mengumpulkan informasi tentang suatu indikasi atau keadaan yang terjadi pada saat ini. Tujuan penelitian diskriptif adalah memberikan kepada peneliti sebuah riwayat atau untuk menggambarkan aspek-aspek yang relevan dengan fenomena perhatian dari prespektif seseorang, organisasi, orientasi industri, atau lainnya yang kemudian penelitian ini membantu peneliti untuk memberikan gagasan untuk penyelidikan dan penelitian lebih lanjut atau membuat keputusan tertentu yang sederhana (Uma Sekaran, 2006).

\section{Populasi Dan Sampel}

Populasi menurut Sugiyono (2014) populasi adalah wilayah generalisasi yang terdiri atas obyek/subyek yang mempunyai kualitas dan karakteristik tertentu yang ditetapkan oleh peneliti untuk dipelajari dan kemudian ditarik kesimpulannya. Populasi dalam penelitian ini adalah perusahaan perbankan yang terdaftar di Bursa Efek Indonesia pada periode 2013 - 2017 berjumlah 43 Bank.(Sumber : Lap OJK 2013-2017), sampel merupakan sebagian populasi yang ingin diteliti yang ciri-ciri dan keberadaannya diharapkan mampu mewakili atau menggambarkan ciri-ciri keberadaan populasi yang sebenarnya.Dimana teknik penelitian yang digunakan adalah purposive sampling yaitu teknik pengambilan sampel sumber data dengan pertimbangan tertentu. Dari batasan tersebut maka diperoleh jumlah sampel sebesar 25 Bank dengan rincian jumlah Bank Umum Pemerintah 4 Bank dan 21 Bank Swasta Nasional (Sumber: Lap OJK tahun 2013 -2017)

\section{Metode Analisis Data}

Uji Paired Sampel $T$ test adalah pengujian yang digunakan untuk membandingkan selisih dua mean dari dua sampel yang berpasangan dengan asumsi data terdistribusi normal. Paired Samples $T$ test digunakan untuk menguji perbedaan rata-rata dari dua kelompok data atau sampel yang berpasangan (Duwi Priyanto,2010).

Hipotesa Statistik

Ho: $\mu 1=\mu 2$, Tidak ada perbedaan signifikan Kinerja Keuangan (ROA dan ROE )Bank Umum Pemerintah (BUMN) dan Bank Umum Swasta Nasional yang terdaftar di BEI.periode 2013 -2017

Ha: $\mu 1 \neq \mu 2$, Ada perbedaan signifikan Kinerja Keuangan (ROA dan ROE)Bank Umum Pemerintah (BUMN) dan Bank Umum Swasta Nasional yang terdaftar di BEI periode 2013 -2017

Pengambilan keputusan berdasar sigifikansi:

Sig > 0,05 Ho diterima

Sig $\leq 0,05$ Ho ditolak

\section{HASIL ANALISIS DAN PEMBAHASAN \\ Deskripsi Data}


Tabel 1

Rata Rata Return On Asset periode tahun 2013 - 2017

Bank Umum Pemerintah Dan Bank Umum Swasta

\begin{tabular}{|c|c|c|c|c|c|c|}
\hline \multirow[t]{2}{*}{ No } & \multirow[t]{2}{*}{ Nama Bank } & \multicolumn{5}{|c|}{$\begin{array}{c}\text { Rata Rata } \\
\text { Return on Asset }(\%) \\
\text { Tahun }\end{array}$} \\
\hline & & 2013 & 2014 & 2015 & 2016 & 2017 \\
\hline 1 & Bank Umum Pemerintah & 2.08 & 2.30 & 2.55 & 5.78 & 2.04 \\
\hline 2 & Bank Umum Swasta & 1.062 & 1.25 & 1.84 & 0.80 & 0.56 \\
\hline
\end{tabular}

Sumber : Data sekunder yang diolah, tahun 2020

Tabel 1 menunjukan rata-rata ROA dari ke empat Bank Umum Pemerintah (BUMN) dari tahun 2013 - 2016 mengalami kenaikan , rata- rata ROA tertinggi dicapai pada tahun 2016 yaitu sebesar 5,78\%, namun pada tahun 2017 rata-rata ROA sebesar 2,04 \% mengalami penurunan yang cukup signifikan dibandingkan dengan tahun 2016 , kontribusi kenaikan yang cukup signifikan rata-rata ROA tahun 2016 dikarenakan ada salah satu Bank Umum Pemerintah terjadi peningkatan adanya kenaikan laba bersih yang diperoleh .Sedangkan laba bersih meningkat disebabkan adanya kenaikan fee based income maupun pendapatan bunga bersih. Tahun 2017 terjadi penurunan rata-rata ROA BUMN penyebab penurunan dikarenakan adanya penurunan ROA pada Bank Tabungan Negara (Pesero) Tbk dan Bank Mandiri (Pesero) Tbk. sedangkan rata-rata ROA dari Bank Umum Swasta Nasional mengalami peningkatan dari tahun 2013 - 2015, namun pada tahun 2016 - 2017 mengalami penurunan yang cukup signifikan adapun kontribusi penurunan rata-rata ROA dari Bank Of India Indonesia Tbk. dimana besarnya ROA yang diperoleh negatif sebesar $(-11,77 \%)$, juga ada beberapa Bank yg mengalami penurunan ROA yaitu Bank Mega Tbk dan Bank Pan Indonesia Tbk.

Tabel 2

Rata Rata Return On Equity periode tahun 2013 -2017

Bank Umum Pemerintah Dan Bank Umum Swasta

\begin{tabular}{|c|c|c|c|c|c|c|}
\hline \multirow[t]{2}{*}{ No } & \multirow[t]{2}{*}{ Nama Bank } & \multicolumn{5}{|c|}{$\begin{array}{c}\text { Rata Rata } \\
5 \text { Return on Asset }(\%) \\
\text { Tahun }\end{array}$} \\
\hline & & 2013 & 2014 & 2015 & 2016 & 2017 \\
\hline 1 & Bank Umum Pemerintah & 17.74 & 18.62 & 19.69 & 42.32 & 15.44 \\
\hline 2 & Bank Umum Swasta & 8.63 & 9.12 & 11.89 & 9.96 & 3.00 \\
\hline
\end{tabular}

Sumber : Data sekunder yang diolah, tahun 2020

Tabel 2 menunjukan bahwa rata-rata ROE dari ke empat Bank Umum Pemerintah (BUMN) dari tahun 2013 - 2016 mengalami kenaikan, rata- rata ROE tertinggi dicapai pada tahun 2016 yaitu sebesar 42,32\%, namun pada tahun 2017 rata-rata ROE sebesar $15,44 \%$ mengalami penurunan yang cukup signifikan dibandingkan dengan tahun 2016, kontribusi rata-rata ROE tahun 2016 meningkat cukup signifikan dari ROE diperoleh dari Bank Rakyat Indonesia (Persero) Tbk, adapun faktor penyebab peningkatan ROE Bank BRI dikarenakan adanya kenaikan laba bersih yang diperoleh .Sedangkan Equitas juga mengalami kenaikan namun 
kenaikan laba bersih lebih besar dari kenaikan ekuitas atau modal sendiri. rata-rata ROE dari Bank Umum Swasta Nasional mengalami peningkatan dari tahun 2013 2015, namun pada tahun 2016 - 2017 mengalami penurunan yang cukup signifikan adapun kontribusi penurunan rata-rata ROE disebabkan adanya ROE yang besarnya negatif . Artinya ada Bank Swasta Nasional yang mengalami kerugian cukup tinggi Analisis Data

Uji Paired Sampel T test digunakan untuk menguji perbedaan rata-rata Kinerja Keuangan yang diukur dengan ROA dan ROE dari Bank Umum Pemerintah dan Bank Umum Swasta Nasional yang terdaftar di BEI periode tahun 2013 -2017

Tabel 3

Paired Samples Statistics

\begin{tabular}{|c|c|c|c|c|c|}
\hline & & Mean & $\mathrm{N}$ & $\begin{array}{c}\text { Std. } \\
\text { Deviation }\end{array}$ & $\begin{array}{l}\text { Std. Error } \\
\text { Mean }\end{array}$ \\
\hline \multirow[t]{2}{*}{ Pair 1} & ROA BUMN & 2,95000 & 5 & 1,595024 & ,713316 \\
\hline & $\begin{array}{l}\text { ROA BANK } \\
\text { SWASTA }\end{array}$ & 1,10240 & 5 & ,488138 & ,218302 \\
\hline
\end{tabular}

Sumber : Data sekunder yang diolah, tahun 2020

Tabel 3 menunjukan bahwa ROA BUMN mempunyai nilai rata-rata (mean) 2,9 dari lima data BUMN, sebaran data ( Std Deviation) yang diperoleh adalah 1,595 dengan standar error 0,7133.ROA Bank Swasta Nasional mempunyai nilai rata-rata 1,102 dari lima data Bank, sebaran data (Std Deviation) yang diperoleh 0,488 dengan standart error 0,218. Hal ini menunjukan ROA BUMN lebih tinggi dari pada ROA Bank Swasta Nasional.Namun rentang sebaran data ROA BUMN juga menjadi semakin lebar dan dengan standart error yang semakin tinggi.

Tabel 4

Paired Samples Correlations

\begin{tabular}{lllll}
\hline & N & Correlation & Sig. \\
\hline Pair 1 & ROA BUMN \& ROA & 5 &,- 231 &, 709 \\
& BANK SWASTA & & & \\
\hline
\end{tabular}

Sumber : Data sekunder yang diolah, tahun 2020

Tabel 4 Tabel Paired Sampel Correlation menunjukan nilai korelasi yang menunjukan hubungan ROA kedua Bank yaitu Bank Umum Pemerintah (BUMN) dan Bank Umum Swasta Nasional.A dapun diperoleh hasil besarnya koefisien korelasi $-23,1 \%$ yang berarah negatif, artinya ada hubungan antara ROA Bank Umum Pemerintah (BUMN) dengan ROA Bank Umum Swasta Nasional yang berarah negatif.

Tabel 5 


\begin{tabular}{|c|c|c|c|c|c|c|c|c|c|}
\hline & \multicolumn{5}{|c|}{ Paired Differences } & \multirow[t]{3}{*}{$\mathrm{T}$} & \multirow[t]{3}{*}{$\mathrm{df}$} & \multirow{3}{*}{$\begin{array}{l}\text { Sig. (2- } \\
\text { tailed) }\end{array}$} \\
\hline & & \multirow[t]{2}{*}{ Mean } & \multirow[t]{2}{*}{$\begin{array}{c}\text { Std. } \\
\text { Deviation }\end{array}$} & \multirow[t]{2}{*}{$\begin{array}{l}\text { Std. } \\
\text { Error } \\
\text { Mean }\end{array}$} & \multicolumn{2}{|c|}{$\begin{array}{l}\text { 95\% Confidence } \\
\text { Interval of the } \\
\text { Difference }\end{array}$} & & & \\
\hline & & & & & Lower & Upper & & & \\
\hline $\begin{array}{c}\text { Pair } \\
1\end{array}$ & $\begin{array}{c}\text { ROA BUMN } \\
\text { - ROA BANK } \\
\text { SWASTA }\end{array}$ & 1,847 & 1,772 & 0,792 & $-0,3531$ & 4,048 & 2,331 & 4 & 0,080 \\
\hline
\end{tabular}

Sumber : Data sekunder yang diolah, tahun 2020

Tabel 5 menunjukan hasil uji hipotesis besarnya probabiltas Sig > 0,05 yaitu sebesar 0,080, maka menerima Ho tidak ada perbedaan yang signifikan Kinerja Keuangan yang di hitung dari Return On Asset (ROA) Bank Umum Pemerintah atau BUMN dengan Kinerja Keuangan (ROA) Bank Swasta Nasional periode 2013 - 2017 di Bursa Efek Indonesia . Hal ini menunjukan bahwa pengelolaan Bank Umum Pemerintah (BUMN) dan Bank Swasta Nasional tidak ada perbedaan, artinya pengelolaan dengan prinsip prudential atau hati - hati dan patuh pada aturan Otoritas Jasa Keuangan. Meskipun Rata ROA BUMN lebih tinggi dari BankSwasta Naional namun tidak perbedaan tersebut tidak berarti karena tidak signifikan.

Tabel. 6

Paired Samples Statistics

\begin{tabular}{llcccc}
\hline & Mean & N & $\begin{array}{c}\text { Std. } \\
\text { Deviation }\end{array}$ & $\begin{array}{c}\text { Std. Error } \\
\text { Mean }\end{array}$ \\
\hline Pair 1 & ROE BUMN & 22,762 & 5 & 11,044 & 4,939 \\
& ROE SWASTA & 8,520 & 5 & 3,326 & 1,487 \\
\hline
\end{tabular}

Sumber: Data sekunder yang diolah, 2020

Tabel 6 menunjukan bahwa ROE Bank Umum Pemerintah (BUMN) mempunyai nilai rata-rata (mean) 22,76 dari lima data BUMN , sebaran data ( Std Deviation) yang diperoleh adalah 11,044 dengan standar error 4,93. ROE Bank Umum Swasta Nasional mempunyai nilai rata-rata 8,52 dari lima data Bank Swasta, sebaran data (Std Deviation) yang diperoleh 3,32 dengan standart error 1,487. Hal ini menunjukan ROE Bank Umum Pemerintah ( BUMN) lebih tinggi dari pada ROE Bank Umum Swasta Nasional.Namun rentang sebaran data ROE Bank Umum Pemerintah (BUMN) juga menjadi semakin lebar dan dengan standart error yang semakin tinggi. 


\begin{tabular}{llccc}
\hline & & N & Correlation & Sig. \\
\hline Pair 1 & ROE BUMN \& & 5 &, 376 &, 533 \\
& ROE SWASTA & & & \\
\hline
\end{tabular}

Sumber : Data sekunder yang diolah, tahun 2020

Tabel 7 adalah Tabel Paired Sampel Correlation menunjukan nilai korelasi yang menunjukan hubungan ROE kedua Bank yaitu Bank Umum Pemerintah (BUMN) dan Bank Umum Swasta Nasional. Adapun diperoleh hasil besarnya koefisien korelasi 37,6 \% yang berarah positif , artinya ada hubungan antara ROE Bank UmumPemerintah ( BUMN) dengan ROE Bank Umum Swasta Nasional yang berarah positif.

Tabel 8

Paired Samples Test

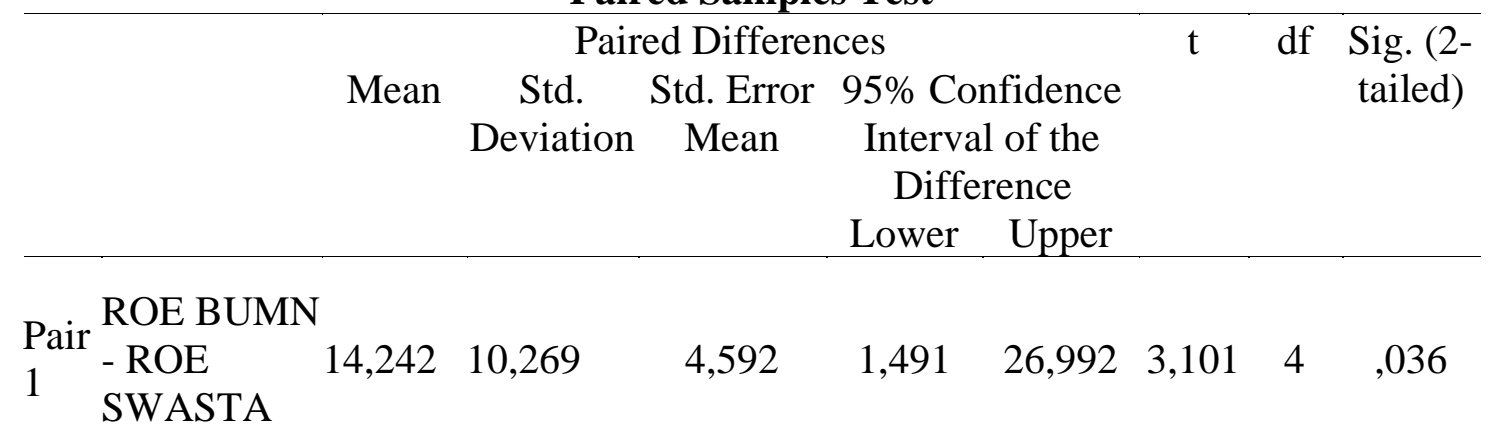

Sumber : Data sekunder yang diolah, tahun 2020

Tabel 8 menunjukan hasil uji hipotesis besarnya probabiltas Sig $<0,05$ yaitu sebesar 0,036 , maka menerima $\mathrm{Ha}$ ada perbedaan yang signifikan Kinerja Keuangan yang di hitung dari Return On Equity (ROE) Bank Umum Pemerintah (BUMN) dengan Kinerja Keuangan (ROE) Bank Umum Swasta Nasional periode 2013 - 2017 di Bursa Efek Indonesia . Hal ini menunjukan bahwa kemampuan untuk menghasilkan laba bersih dibandingkan dengan modal sendiri atau Equity ada perbedaan yang signifikan Bank Umum Pemerintah (BUMN) dan Bank Swasta Nasional, hal ini dapat dikarenakan investor lebih percaya kepada Bank Umum Pemerintah (BUMN) dalam menjalankan investati sehingga menyebabkan saham Bank Umum Pemerintah (BUMN) lebih diminati di BEI juga dikarenakan ROE sebagai indikator penting bagi calon investor dan bagi pemegang saham , rata- rata ROE Bank Umum Pemerintah lebih tinggi dibandingkan dengan ROE Bank Umum Swasta Nasional, tingginya ROE itu disebabkan karena laba bersih yang diperoleh Bank Umum Pemerintah juga tinggi. Laba bersih yang dicapai meningkat juga didiringi dengan kenaikan equity, namun kenaikannya masih lebih besar laba bersih dibanding dengan kenaikan equity sehingga menyebabkan ROE akan meningkat.

\section{PENUTUP}


Rata -rata Return On Asset (ROA) Bank Umum pemerintah (BUMN ) lebih tinggi bila dibandingkan dengan Return On Asset (ROA) Bank Umum Swasta Nasional periode tahun 2013 - 2017. Rata-rata ROA tertinggi Bank Umum Pemerintah (BUMN) sebesar 5,78 \% pada tahun 2016, dan ROA Bank Umum Swsata Nasional tertinggi sebesar $1,84 \%$ pada tahun 2015.

Rata- rata Return On Equity (ROE) Bank Umum Pemerintah (BUMN ) lebih tinggi dibandingkan dengan Bank Umum Swasta Nasional periode 2013 2017.Rata-rata ROE tertinggi Bank Umum Pemerintah (BUMN )dicapai pada tahun 2016 yaitu sebesar 42,32 \% , dan ROE Bank Umum Swasta Nasional sebesar 11,89 \% dicapai pada tahun 2015. Dengan uji paired sampel test diperoleh hasil tidak ada perbedaan rata -rata Return On Asset (ROA) Bank Umum Pemerintah (BUMN) dan rata-rata Return On Asset (ROA) Bank Umum Swasta Nasional yang terdaftar di BEI periode tahun 2013 -2017. Hal ini disebabkan bahwa Bank dalam mengelola usahanya selalu menggunkan prinsip prudential atau kehati hatian dan azaz kepatuhan tetap dilakukan, sehingga akan menyebabkan laba bersih meningkat dan penggunaan asset secara efisien.Hasil penelitian ini bertolak atau tidak mendukung penelitian yang dilakukan oleh Yuli Christian (2009), perbedaan hasil analisis yang berbeda dikarenakan kondisi tahun analisis yang berbeda dan pada tahun 2012 terbentuknya Otoritas Jasa Keuangan (OJK) yang mempunyai kebijakan dan inisiatf untuk mendukung kinerja lembaga keuangan, salah satu kebijakan memanfatakan tehnologi dalam proses bisnis, termasuk pengawasan dan pengajuan ijin. Dengan kondisi tersebut maka Bank Umum Pemerintah (BUMN) dan Bank Umum Swasta Nasional dalam menjalankan binis tidak ada perbedaan dalam penggunaan tehnologi sebagai aset Bank.

Dengan uji paired sampel test diperoleh hasil ada perbedaan rata-rata Return On Euquity (ROE) Bank Umum Pemerintah Dan Bank Umum Swasta Nasional yang terdaftar di BEI periode tahun 2013 -2017. Rata-rata ROE Bank Umum pemerintah (BUMN ) lebih tinggi dari pada rata-rata ROE Bank Umum Swasta Nasional ,hal ini disebabkan bahwa ROE merupakan indikator yang penting bagi pemegang saham maupun calon investor Bank Umum Pemerintah (BUMN ) lebih mendapat kepercayaan dari calon investor sehingga saham akan lebih diminati oleh calon investor dibandingkan dengan saham Bank Umum Swasta Nasional.Dengan adanya tambahan equity akan menyebabkan bertambahnya modal sehingga akan berdampak pada capaian laba bersih . Faktor lainnya juga dapat disebabkan bahwa pada umumnya produk jasa bank lainnya pada Bank Umum Pemerintah (BUMN) lebih banyak, kondisi ini juga menyebabkan pendapatan dari fee based income yang tinggi maka laba bersih juga akan tinggi. Hasil penelitian ini sejalan dengan penelitian terdahaulu yang dilakukan oleh Abraham M dan Dwi Umardani (2016).

Beberapa saran yang dapat dikemukakan dari hasil penelitian ini adalah sebagai berikut ini.Bagi investor yang berminat melakukan investasi pada sektor bank lebih baik jika melakukan investasi tersebut pada bank umum pemerintah karena bank umum pemerintah mempunyai rata-rata kinerja keuangan yang lebih tinggi. Bagi regulator atau Bank Umum Pemerintah seharusnya dapat melakukan pengawasan melalui regulasi yang ditetapkan untuk menjaga kinerja perbankan sehingga dapat menjamin kepentingan para nasabah dan pemegang saham dari kemungkinan kerugian akibat adanya kinerja yang buruk dari bank umum swasta nasional. 


\section{DAFTAR PUSTAKA}

Abraham dkk 2016, Analisis Perbandingan Kinerja Keuangan Bank Syariah Dan Bank Konvensional Di Indonesia.

Bank Indonesia (2007) Peraturan Bank Indonesia Nomor. 9/1/PBI/2007 Tentang Sistem Penilaian Tingkat Kesehatan Bank Umum Berdasarkan Prinsip Syariah, Tanggal 24 Januari 2007.

Bank Indonesia (2011) Surat Edaran Bank Indonesia Nomor13/24/ DPNP Tentang Penilaian Tingkat Kesehatan Bank Umum, Tanggal 25 Oktober 2011.

Dendawijaya, Lukman. 2005. Manajemen Perbankan. Jakarta, Ghalia Indonesia.

Duwi Priyatno (2010) , Tehnik Mudah Dan Cepat Melakukan Analisis Data Penelitian, Gaya Media Yogyakarta

Halim, Abdul dan Mamduh M. Hanafi. 2005. Analisis Laporan Keuangan. Yogyakarta, AMP-YKPN

Harahap, Sofyan Syafri. 2015. Analisa Kritis atas Laporan Keuangan. Jakarta, PT Raja Grafindo Persada.

Ikatan Akuntansi Indonesia. PSAK No. 1 Tentang Laporan Keuangan- edisi revisi 2015. Penerbit Dewan Standar Akuntansi Keuangan: PT. Raja Grafindo

Kuncoro, Mudrajad. 2007. Metode Kualitatif Teori dan Aplikasi untuk Bisnis dan Ekonomi. Yogyakarta, UPP STIM YKPN

Kasmir. 2014. Analisis Laporan Keuangan. Jakarta, PT Raja Grafindo Persada.

Munawir. 2014. Analisis Laporan Keuangan. Yogyakarta, Liberty

Sugiyono. 2014. Metode Penelitian Kuantitatif Kualitatif dan R\&D. Bandung, Alfabeta.

Tandelilin, Eduardus. 2010. Portofolio dan Investasi: Teori dan Aplikasi. Edisi 1. Yogyakarta, Kanisius.

www.idx.co.id/perusahaan-tercatat/laporan-keuangan-dan-tahunan (Diakses pada bulan April 2019)

www.sahamok.com/emiten/sektor-keuangan/sub-sektor-bank (Diakses pada bulan Maret 2019)

https://investasi.kontan.co.id/news/saham-bank-diprediksi-akan-terus-melajudi-kuartal-ii-2019 (Diakses pada bulan Juni 2019)

Darsono dan Ashari (2004) Pedoman Praktis Memahami Laporan Keuangan, Penerbit Andi, Yogyakarta.

Yuli Christian (2009), Analisis Perbedaan Kinerja Keuangan Bank Umm Pemerintah Dan Bank Umum Swasta Nasional Dengan Menggunakan Rasio Keuangan Periode tahun 2003 - 2007, digilib.uns.ac.id 